\title{
Panḍānī Heroines,
}

\section{Chhattisgarhi Daughters}

\section{Pandvā̄ī}

The Sanskrit, pan-Indian epics of the Ramayana and Mahabharata are often paired in Western scholarship of South Asian texts, even as that pairing reveals significant differences between the two (see, for example, Shulman I99I and Smith 1980). ${ }^{1}$ More recent field-based scholarship suggests that in folk performance, however, the two traditions are rarely paired and, in terms framing this study, do not fall within the same performative repertoire and intertextual system of genres (Hiltebeitel I988; Lutgendorf I99 I; Sax I99 I; Smith I990). In Chhattisgarh, the Mahabharata folk genre of pandvāni (the name taken from the five Pandava brothers/heroes of epic) is called a Chhattisgarhi genre, whereas the much more commonly performed Ramayana tradition, available in a wide variety of performance styles, is not. In this chapter, I consider what difference it makes to indigenous understandings of

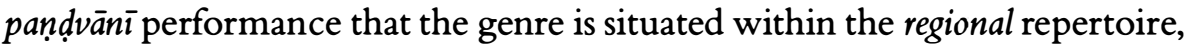
or system of genres, in which it is continually paired with the regional candaini epic. Focusing specifically on performance of the pandvāni narrative episode of $\mathrm{Nal}$ and Damayanti, ${ }^{2}$ what kind of commentary-sometimes only

${ }^{1}$ The Sanskrit analytic terms for the two epics distinguish them as separate genres: itihasa (history) for the Mahabharata and kā $y a$ (poetry) or caritra (biography) for the Ramayana. The distinction is a literary one, however; one of the pandvāni singers to whom I spoke used caritra for the Mahabharata narrative in the general sense of "story."

${ }^{2}$ Note that I use the Hindi transliteration Nal instead of the Sanskrit transliteration Nala. I specifically elicited the $\mathrm{Nal}$ and Damayanti episode from the pandvāni singers I met in the summer of 1993 in anticipation of a paper I presented in November I993 at the Wisconsin Annual Conference on South Asia on a panel titled "Nala and Damayanti: Varying Visions of Love and Self." 
hints thereof-does this intertextuality provide us for how the narrative may be received and interpreted in situated performance?

\section{“According to Our Hearts": A Chhattisgarhi Genre}

In search of pandvāni performers in the summer of I993, I set out during an evening hot-season dust storm, on the back of the scooter of an anthropologist from Ravishankar University, for the village of Darba, about an hour east of the city of Raipur. Over ten years earlier in this village, I had recorded a pandvān $\bar{\imath}$ performance, which happened to be of the $\mathrm{Nal}$ and Damayanti episode, from a middle-aged blind singer of the Marar (vegetable-seller) caste. I hoped that he would still be living, would be willing to perform this narrative segment again, and that he and others would be able to provide some insight on pandvānī as a Chhattisgarhi genre.

During the year and a half I had spent in Chhattisgarh from I980 to I98 I and on several return visits since then, pandvāni was consistently mentioned as a central genre of the repertoire of genres identified as Chhattisgarhi. There had been, however, no pandvāni performances during this time in any of the villages or urban neighborhoods in which I had lived or visited, except for that of the above-mentioned blind singer. At that time, although the memory of pandvani performance still helped to identify and characterize the Chhattisgarhi folklore region through frequent reference, few living performers still regularly sang pandvāni in public, professional contexts.

In contrast, the candain $\bar{i}$ epic tradition was continually in the public eye (and "ear") through local performances, in government-sponsored competitions, in the news media, and on the radio. In the late I970s and early I980s, exposure of this epic tradition outside Chhattisgarh was promoted by the playwright and director Habib Tanvir (mentioned in Chapter 6), who wrote a contemporary dramatic work based on candainī. Using Chhattisgarhi actors and traditional performers, he staged this work in New Delhi and other urban centers, even as far away as London.

Over the last five to seven years, pandvāni performance has experienced a dramatic performance revival and popularity comparable with that of candain $\bar{\imath}$ in the I980s, particularly as representative of "things Chhattisgarhi." Like candaini, it has come to represent the region among folklore and intellectual circles outside Chhattisgarh, in various government-sponsored performance competitions, as well as on radio and television. This has largely been due to the influence of one particular female pandvānī singer, Tijan Bai, in whom, according to many Chhattisgarhi residents, the government (and 
subsequent audiences and singing competition judges) showed particular interest because of her uniqueness as a woman in public, professional performance. ${ }^{3}$ Her grandfather was a performer and she says she informally learned from him at an early age, never having been discouraged from doing so for being a girl. Even after she began to perform publicly, she continued working as a laborer in one of the Bhilai steel mills and, at the same time, earned her high school equivalency degree. A few other girls have followed in her

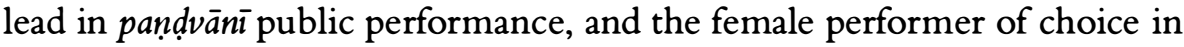
the media in I993 was the sixteen-year-old Ritu Varma. I heard several comments that year by residents in Raipur and Dhamtari that Tijan Bai was losing her popularity to Ritu Varma because of her age (the former was about thirty-five years old at the time).

Tijan Bai has appeared frequently on Doordarshan (the governmentsponsored television channel), sings in various folk festivals in Delhi and other urban centers, has received various national-level performance and artistic awards, and participated in the Festival of India in Paris during the summer of I993. She dresses the part of a "typical" Chhattisgarhi villager, wearing easily identifiable Chhattisgarhi jewelry, although some pieces are actually seen only rarely in the gullies and streets of Chhattisgarh today (because of both the expense of gold and the attitude held by educated women that this jewelry is "backward"). Tijan Bai accompanies herself on a colorfully decorated and painted tambürā (single-stringed instrument), which has come to be identified specifically with pandvāni performance. Her success and popularity has revived pandvāni performance all over Chhattisgarh in a variety of contexts. Hence, I anticipated an increased awareness of the genre in the village in which we found ourselves on that hot, dusty evening in May.

The Brahmin village headman with whom I had stayed in Darba village and in whose courtyard I had taped pandvān those many years earlier had since moved to Raipur to live with one of his sons. His large, double-storied house in the middle of the village was now empty except for a few servants and his Brahmin daroga (overseer of the estate). After cups of tea and general discussion with the daroga and several other men who had gathered in the courtyard about shifting caste dynamics caused by industrialization in nearby Raipur and an associated demise of many Chhattisgarhi folk performance genres, the darogā assured us that the blind pandvāni singer, Mani Ram, was

${ }^{3}$ I have made efforts to meet Tijan Bai over the last few years, but she has always been "out of station" whenever I have visited Chhattisgarh. In the summer of I993, when she was constantly referred to as the pandvāni singer whom I should meet and record, my standard answer became that I would need to go to Delhi or France to hear her-an answer that delighted and amused her referees. Most of them had themselves heard her only over the radio or on cassette tapes, never in live performance. 
still living and sent someone to call him. Meanwhile, he asked if we would like to watch a tape of the televised Mahabharata on the VCR while we were waiting. I hesitated, feeling somehow that this would "corrupt" the setting for what I hoped would be the forthcoming pandvāni performance as soon as the singer arrived. However, the question was rhetorical; and soon, seated in the courtyard under a dark, moonless sky, a group of twenty or so children, women, and the male servants of the estate were gathered with rapt attention in front of a tiny black-and-white screen on which stiffly acted characters spoke Sanskritic Hindi that few of the audience could fully understand.

To my dismay, the drone of the Mahabharata on the VCR continued as a backdrop to our conversation when Mani Ram finally did arrive at I I:00 P.M. or so. It was now too late to start a performance; but, he assured me he would return in the morning to sing (albeit then without the naturally congregated audience that was present late that night). The TV performance, however, provided an important opening in my conversation with the singer. When I asked him what difference there was between this "TV Mahabharata" and pandvānī, his answer was immediate and decisive: "The Mahabharata of the TV is according to the śästra [authoritative, religious texts]; pandvān $\bar{\imath}$ is according to our hearts. Pandvān $\bar{\imath}$ is Chhattisgarhi." In a neighboring village, another singer gave me a similar response: "The TV is for everyone; there are many written Mahabharatas. This [pandvānī] stands alone. Those who read from paper, they know the TV Mahabharata." 4

A third singer, Pancam, who makes his living as an electrical appliance (radios, televisions, fans) repairman was puzzled when I expressed to him my specific interest in the $\mathrm{Nal}$ and Damayanti narrative and asked him if this episode was in the repertoire of his performance troupe. He assured me it was, but asked:

[Pancam:] Can't you do this research by reading? Whatever you want to know, you'll find in writing.

[Indian anthropologist who accompanied me to this village]: No, there's some difference between the books and what you sing. The things you enjoy [ $m a-$ jedār bāt], like the weddings of Sahadev and Nakula [the twin Pandava brothers], you won't find those there.

[Pancam:] If you printed everything we sing and put it in the bazaar [that is, in books to sell], it would take up from here to there [extending his arms out wide]. But, that's stopping now. At first, those who sang pandvāni sang every

4 "tv sabhon ke hai; bahut likhe mahäbhārat hai. yah ekton ke hai. jo khāgaz se parte, unko tv mahābhārat malūm hai." 
detail: they came by this road, they passed this village-they sang about every well, river, and taläb [tank]. Nowadays, what do they do? They come from there 'direct's to here.

What does it mean for a performance genre to be "Chhattisgarhi," to be sung according to the heart rather than the sasstra? Note that in the following discussion, I will use the word śastra/shastric with the connotations implied in this statement by Mani Ram-as a textual or textually based performance tradition shared across regional boundaries, to be distinguished from what are perceived to be uniquely Chhattisgarhi (regional) oral traditions. ${ }^{6}$

I must admit that I first looked for the answer to this question in the verbal, transcribed texts of the three full performances of the Nal and Damayanti narrative that I recorded in the summer of 1993 , suspecting that the Chhattisgarhi variants of the narrative would reflect a particularly regional, rather than what our singer calls "shastric" (and I gloss as Sanskritic/brahminic), vision of women, fate, and divine intervention (such as I had found in comparing the candain $\bar{i}$ regional epic with the caste tradition of U.P.). While many of these can be found, the pandvāni performance styles themselves and the genre's place within a distinct repertoire are just as crucial in its definition as a Chhattisgarhi genre.

\section{The Nal and Damayanti Narrative}

These Chhattisgarhi performances reflect numerous regional variations and localizations, but on the level of plot, the performances follow the general contours of the Sanskrit narrative amazingly closely. ${ }^{7}$ Perhaps this should not be surprising, since the shastric narrative of $\mathrm{Nal}$ and Damayanti already shares certain features that seem to characterize the alternative regional vision expressed in genres such as candaini. As J. A. B. van Buitenen elaborates in the introduction to his translation of Book 3 of the Sanskrit

${ }^{5}$ Words in single quotations indicate English words that were used in otherwise Chhattisgarhi or Hindi conversations.

${ }^{6}$ The shastric/Chhattisgarhi distinction in this context is equivalent to the märga/desit distinction referred to by Blackburn and Ramanujan as "[the] contrast often cited by scholars (but rarely used by the folk themselves) as an indigenous Indian expression of a folk/classical contrast. In fact, these terms represent only different (the local and pan-Indian) expressions of the same tradition, not different traditions" (I986:I4).

7 The skeleton of the narrative is quite readily available in the performance Mani Ram sang the morning after the video showing. The performance was only an hour long and disappointingly perfunctory, for he remembered having sung it for me over ten years before and could not understand why I had asked for this particular narrative again. I rather lamely explained that the tape had gotten old. 
Mahabharata, The Book of the Forest (I975:I82-I85), Nal and Damayanti is already a female-centered tale, with an active heroine, and a narrative with a folktale-like, domestic quality.

This story of the heroine Damayanti and hero Nal is told to the Pandava eldest brother Yudhishthira (in forest exile, mourning the loss of his kingdom through dicing) by the rși Brihadashva, as the story of a prince who had suffered even more greatly than he. Nal, king of Nishadha, was the most beautiful of men and Damayanti the beautiful princess of Vidarbha. A pair of geese serves as matchmaker between the two, sparking the love between them through descriptions of their respective beauty. Damayanti's lovesickness is reported to her father, who decides it is time to call for her swayamvar (the ritual in which a princess publicly chooses a husband from among her suitors by garlanding him). Kings and princes from all over the world arrive in hopes of being chosen by the exquisite princess (the swayamvar characterized, in one Chhattisgarhi performance, as a 'beauty competition,' to which "kings from 'America,' 'England,' 'Australia,' everywhere" arrived). Nal adorns himself and joins in the migration toward Vidarbha.

The gods, too, hear of the swayamvar; and four of them decide to attend. In the Sanskrit version, they truly hope that one of them will be chosen as the bridegroom, whereas in the Chhattisgarhi version, they attend the swayamvar to test the love of $\mathrm{Nal}$ and Damayanti. On the way, they meet Raja $\mathrm{Nal}$ and ask that he serve as their messenger to the princess, informing her of their intentions. Nal miraculously finds entry into the palace and delivers the message, to which Damayanti replies that because this is a ritual of true selfchoice, she will marry only Raja Nal. When the gods hear her reply, they arrive at the swayamvar as (what the Chhattisgarhi singer calls) 'duplicates' of Nal. In the Sanskrit version, the princess beseeches the gods, by the power of her truthfulness, to reveal their divinity; only then is she able to discern who among the five is the human Nal because only the gods do not sweat, blink, or touch their feet to the ground. The kings and gods return to their respective realms, rejoicing in what they know to be an auspicious match.

One god, Kali, however, was late to the swayamvar. Angered, he vows to make the princess pay for her choice of a human over the gods by unseating $\mathrm{Nal}$ from his kingdom. For twelve years, however, the nearly perfect $\mathrm{Nal}$ commits no transgression through which Kali can initiate his plan. Then; one morning, Nal fails to perform the appropriate ablutions before worshiping; this is Kali's opportunity to enter his body and take advantage of his defects (durgun). As the Chhattisgarhi Kali says, "Every man has his defect, and Nal's is dicing." Kali sends his brother Dvarpa to persuade Nal's brother Pushkar (who had already lost everything he owned through dicing) to challenge $\mathrm{Nal}$ to an all-out dicing competition. Protesting that he has 
nothing to stake, in the Chhattisgarhi version, Kali gives Pushkar two oxen. The dices are loaded, and beginning with the oxen, Nal loses all his possessions until he and Damayanti are left with only a single garment each; and they are banished to the forest.

Upon Pushkar's threat of hanging anyone who helps the couple, no subject offers them even a drop of water. After three days, Nal sees a pair of birds and throws his only garment over them in an effort to capture them for food; but they fly off, leaving the prince naked. Now the couple wanders the forest sharing Damayanti's single sari. Nal tries to persuade his wife to return to her mother's place without him, but she is a true pativrata (faithful wife) and refuses. One night, as the couple has lain down to rest and Damayanti has fallen fast asleep, Nal carefully cuts the shared sari in two and abandons his love at the crossroads.

Damayanti awakens to find herself alone and desperately calls out for her husband before realizing her dreadful fate. She has numerous adventures in the forest and kingdom of Cedi before finally finding her way back to her father's kingdom of Vidarbha. Nal, meanwhile, has his own forest adventures. He saves a snake from a fire and is repaid with only a snakebite, which leaves him cruelly deformed. But the snake assures him that because of this deformity, no one will recognize him in his exile. He promises the prince that the poison that has entered his body will afflict only Kali and will cause him no pain; further, he will always be victorious in battle. He advises Nal to off er his services as a charioteer to the king of Ayodhya.

Meanwhile, Damayanti has sent scouts throughout the land to look for her husband. She instructs them to ask of all they meet a riddle that only $\mathrm{Nal}$ will be able to answer. ${ }^{8}$ One such scout enters the city of Ayodhya with the riddle, and the king's charioteer gives the answer. When Damayanti hears his answer, she knows $\mathrm{Nal}$ is alive and holds a second swayamvar, hoping to lure him back from his exile. The king of Ayodhya instructs his charioteer, the disguised $\mathrm{Nal}$, to deliver him to the swayamvar in a single day. On the way, they pass a vibhitaka tree, and the king, wishing to display his skill in counting, tells $\mathrm{Nal}$ the difference in the number of leaves and nuts on the tree and those on the ground. Nal insists on stopping to verify the count; it is exactly as the king has said. Nal then asks for the knowledge of this magic, offering in return the secret of his charioteering skills. As soon as $\mathrm{Nal}$ receives the secret of counting (the secret of dice), Kali is vomited out of his mouth.

At Vidarbha, Damayanti sends her servant to ask the identity of the deformed charioteer who makes the chariot fly as only Nal can do. She poses a series of tests through which she knows that he can be, in fact, only her

${ }^{8}$ See Shulman 1994 for a discussion of the riddle in the Nal and Damayanti narrative. 
love. Finally, Nal admits who he is; and after a three-year separation, the couple is reunited. Nal returns to his own kingdom to challenge his brother Pushkar to one final dicing, through which he successfully reclaims his throne. And so, the narrator asks the Pandava Yudhishthira, "Hearing of the misery and grief of Raja Nal, what is the basis of your complaint?"

\section{Candain̄ and Paṇ̣̂ānī: A Dialogic Relationship}

What most differentiates pandvāni performance from shastric performance genres available in Chhattisgarh, most notably Tulsidas's Rämcaritmānas, are the identifiable regional styles and contexts in which it is performed: the instruments used in accompaniment, the use of a raggi (echo voice and companion to the lead singer), the ragg (melodic structure) itself, as well as the identities of both performers and audience and the traditional and newly emerging contexts in which pandvān $\bar{\imath}$ is sung. Further, its performance is episodic (characteristic of Indian oral epics such as candaini), rather than approximating the recitation style of devotional texts such as the Ramcaritmānas, which are often cited "from beginning to end" (either over the period of seven, nine, or thirty days or on a weekly basis) until they are completed. One young apprentice singer exclaimed, "Who knows the beginning; who knows the end!" A nonprofessional female performer said, "There are eighteen nights of pandvāni, but I know only bits and pieces." 9 These performance elements situate pandvāni in a regional, Chhattisgarhi system of genres and poetics quite distinct from the coexisting shastric repertoire. It is these genres with which pandvāni interacts dialogically-these intertextual relationships that provide the primary lens through which pandvāni performance, including that of the narrative of $\mathrm{Nal}$ and Damayanti, is interpreted by the Chhattisgarhi folklore community. M. M. Bakhtin characterizes this process of intertextuality as follows: "Utterances are not indifferent to each other, and are not self-sufficient; they are aware of and mutually reflect one another. ... Each utterance is filled with echoes and reverberations of other utterances to which it is related by the community of the sphere of speech" (I986:9I).

9 There are a limited number of episodes of the "unending" Mahabharata narrative current in pandvāni performance, although many more episodes of the narrative may be part of the oral tradition, that is, known to the audience members through other performance genres as well as the televised serialization of the Mahabharata (see footnote is below for those available on cassette tape in Raipur in the summer of 1993). I have not attempted to contextualize the $\mathrm{Nal}$ and Damayanti narrative within this unbounded Mahabharata oral tradition/repertoire of episodes except as the performers themselves have done so, for it would be conjecture on my part as to what episodes are known or unknown to Chhattisgarhi audiences. 
As mentioned earlier, the genre with which pandvāni is most closely associated in Chhattisgarh is the epic candaini. In fact, the Brahmin overseer of the rural estate in Darba village, as someone who does not participate directly in the tradition as performer or audience member but who is quite conversant with the folk repertoire performed in his village, frequently confused the two genres in our conversation. When I asked him the contexts in which pandvāni is performed these days in his village, he began describing a performance group in a neighboring village that was hired for particular festivals. I recognized that this was the same candaini troupe that I had recorded twelve years earlier and asked, "Do you mean candaini??" He quickly caught himself, "Yes, yes. Candaini. Well-pandvānī; they do it all." The electricalrepairman singer mentioned above, the leader of a six- to eight-member performance troupe, characterized contemporary pandvāni performance:

These days, anyone can sing pandvāni [that is, it is possible that a group that had sung candaini exclusively twelve years ago would have begun to sing pandvānī in the interim]. Harijans, whom we call Satnamis, used to sing pandvānī. Rauts sang candaini and the songs of the flute [băs git $]$. And we [Sahus] sang rāmsaptah [term used for particular style of Ramayana performance in Chhattisgarh]. In the old days, a few people knew pandvānī. Tambūrāiâala [literally, belonging to the stringed instrument tambūrā]-that's what people called pandvāni-and manjīi $\bar{a}$ [a kind of cymbal]; there used to be just two [instruments]. Now there are lots of instruments. [To add the phrase] "Listen, son; listen, brother"that's Mahabharata caritra [literally, biography, but here, more generally "story"]. ${ }^{10}$ You can tell the story [kathā] in two minutes or two days; that's what it's like.

Pandvāni and candaini have followed a remarkably similar course of stylistic development over the last fifteen years. Initially, both were sung a cappella, with a lead singer and a single companion $(r \overline{a g} \bar{l})$. The Darba singer Mani Ram, who still sings in this style, said the only difference between candaini and pandvani is that singers of the former add tor or mor to the end of every line and pandvāni singers add bhā ya or bhäige (literally, brother). The style is composed of short, almost staccato couplets of nearly repetitious lines. Each couplet advances the story line, and little room exists for elaboration of scene or emotion or for commentary on motivation. Mani Ram added rather sadly that this traditional singing style is extremely rare these days in Chhattisgarh: "People have no interest without instruments."

${ }^{10}$ Notice the characterization of pandvānī by its "tag phrase," bhāìya mor, a characterization repeated below by the singer Mani Ram. 
Of these two traditions, candaini performers were the first to experiment with shifting styles, adding instrumentation (minimally a harmonium and dholak [a kind of drum]) and more singers. Songs are interspersed with the narrative line of the lead singer, elaborating a bhāv (emotion) or indicating passage of time or the transversing of space. These days, the most popular candain $\bar{i}$ style is that of the dance-drama with costumed actors (nācā). The chief identity of the singers shifted in this period from that of the $\mathrm{R}$ auts to primarily Satnamis. It was during this period that urban elites began to show interest in the regional epic.

The pandvāni tradition followed a similar development about a decade later: the performance style of the "old days" with the single singer and a companion; and more recently, the addition of instrumentation (specifically the brightly decorated tambürā) and a large performance troupe, which have become crucial to reviving pandvāni as a popular style. It has not yet been adapted, however, to the nāca. Like candainī, the identity of pandvāni singers has expanded beyond the boundaries of its traditional performance group, Satnamis, to include a wide spectrum of castes. Finally, the "exterior of the text," to borrow a phrase from Wendy Doniger (I991:32), has come to represent the region to intellectual and cultural performance communities outside Chhattisgarh with particular interests in "things ethnic."

Pandvāni and candaini "new style" singers employ almost identical formulas to indicate breaks between episodes or the passage of time: "And so, they began to say, began to speak, ohhh" or "began to go, began to move, ohhh." "Contemporary pandvāni and candaini performance styles also share the presence of a ragi (respondent), who interacts with the lead performer in spoken narrative. The răg $\vec{\imath} \mathbf{s}$ comments are often the occasion for local humor; they differ from the humorous interludes in rāmlīa dramatic performances because they are not performatively distinct episodes or interludes but punctuate and are integrated into the primary narrative. "Listen" to the following excerpt taken from the first few minutes of the performance, when the lead singer, Manmohan (whose performance we will look at more carefully later in the chapter) is describing Damayanti's fragile state of viraha (separation from her love, $\mathrm{Nal}$ ):

Singer: The rājkumārīs [unmarried princess] condition deteriorated.

Damayanti burned in the fire of separation, in the separation from the love of Raja Nal.

Ragi: Oh, with the fever of timbu [local vegetable]?

11 "kathāvan lāge, bolan lāge, 000" or "calan lāge, jāvan lāge, ooo." 
Singer: No, in the fever of love. The rājkumārī worried twenty-four hours a day; she was struck with worry; she was immersed in thought.

Ragi: Oh, she worried about the tap [play on words between word for tap/nal and name of the hero/Nal]!

Singer: No, no! This is about Raja Nal, not about 'boring' [the term in Chhattisgarh for tube wells]!

Beyond the emergence of similar performative styles, performers of the two genres of candaini and pandvāni employ several narrative motifs and formulaic descriptions that resonate with each other in performance. The heroines Candaini and Damayanti are both Chhattisgarhi daughters, identified by the formulaic sixteen śmgār (adornments), ${ }^{12}$ several of which are unique to Chhattisgarh and worn by female professional pandvāni singers such as Tijan Bai (for example, the bandüriya necklace and kankanī armband). In contrast, the Ramayana heroine Sita is described and visually portrayed in lithographs and rāmlì $\bar{a}$ as wearing vaguely generic north Indian royal clothes and jewelry. The two heroines are also accompanied by the formulaic "fourteen companions, seven in front and seven behind"; they live in similar seven-storied palaces, in quarters tightly guarded, into which the heroes of their tales must try to enter.

Because of the generic association and performative relationship between candain $\bar{\imath}$ and pandvānī, audience members who hear of the daughter Damayanti stranded in the middle of the jungle, threatened by a hunter, are more likely to make an association with the heroine Candaini in the jungle (described in Chapter 6), where she relies on her own ingenuity to get out of a similar situation, than with Sita in her forest dwelling, from which she is kidnapped. Damayanti is not, of course, the eloping Candaini. She is a pativrata (faithful wife) and finally depends on the power of her sat (truth, that is, chastity) to escape the hunter who attempts to accost her in the jungle after she has been deserted by $\mathrm{Nal}$; but the power is humanized. In Mani Ram's performance of this episode, Damayanti successfully curses the hunter but then wanders the forest as a crazy woman whose sanity is restored only when she tells her story to those who take her in as a daughter (an indigenous commentary on the power of story and performance). In these lines, Mani Ram specifically uses the term noni, the affectionate term for daughter in several dialect variants of Chhattisgarhi. In the performance by the Sahu-

12 These include ankle bracelets, a silver waist belt, bracelets, a chain in the part of her hair, a beautiful sari and blouse, red dye (mahur) on her feet, and henna on her hands. 
caste singer, Damayanti also finally resorts to her power as a pativratā to curse the hunter to die, but not before trying a strategy available to all Chhattisgarhi women, that is, appealing to the stranger as a daughter, a sister. ${ }^{13} \mathrm{His}$ own inhumane self is underscored by the fact that he cannot be shamed into responding appropriately to this strategy.

The dicing motif shared between the two traditions, and yet distinctively different, is of particular interest to us here, given the centrality of dicing to the $\mathrm{Nal}$ and Damayanti narrative. Recall from our discussion of candaini that as Lorik and Candaini are passing through an all-female kingdom, Lorik, disguised in a sari, is sent into the city by Candaini to buy some pān. He is enticed into the home of the pann-seller, who threatens him with a series of physical abuses unless he promises to marry her. When Candaini finally comes looking for him, she secures his release by winning him back in a dicing duel with the pan-seller. The motif of women, rather than men, winning and losing partners through dicing is common in several other Chhattisgarhi folk narratives as well (for example, in the Song of Subanbali discussed in Chapter 3), a motif that presents us with an alternative to the more shastric pattern of male dicing for a woman (or a man putting up a woman as stake in that dice game) ${ }^{14}$ The latter is, of course, central to the main story of the Mahabharata in which Yudhishthira dices against Duryodhan (whose uncle Shakuni throws the dice on his behalf). The Pandava king stakes his wealth, his brothers, himself, and finally his wife Draupadi. Dicing in the $\mathrm{Nal}$ and Damayanti narrative follows this same pattern, and Chhattisgarhi audiences surely make the association between the two narratives of dicing and loss, as it is explicitly stated by the narrator of the storywithin-a-story.

However, because pandvān $\bar{\imath}$ is itself situated with a "Chhattisgarhi" repertoire, alternative dicing images and gender ideologies from this repertoire also come into play and frame the reception of Nal's dicing. It makes a difference to this reception that Damayanti is characterized as a Chhattisgarhi daughter (interestingly, $\mathrm{Nal}$ remains more distant, always addressed

13 Damayanti uses this same strategy to persuade the gods who appear at her swayamvar in the form of $\mathrm{Nal}$ to reveal their true forms.

${ }^{14}$ Alf Hiltebeitel reports an episode of female dicing from a Telugu folk Mahabharata tradition in which Draupadi (wife of the five Pandava brothers) plays a game of dice to recover her husbands' lost kingdom, even after she herself has been humiliated in the dice game between Yudhishthira and Duryodhan. She is triumphant in her efforts (dicing directly against Duryodhan this time, not Shakuni); but the Pandavas refuse to take back their kingdom under these conditions, "preferring to win it back in battle and on their own" (1988:238). Hence, the suggested alternative ideology of gender and power is not totally "played out," as it is, for example, in the Song of Subanbali. 
as Raja, "king"). In one performance, the singer directly localizes or resituates the dicing between the brothers $\mathrm{Nal}$ and Pushkar when he characterizes it to be like the custom of male friends and relatives gambling through the night as they celebrate the Chhattisgarhi festival of gaura. The performer rhetorically asks his audience, "After all, don't all brothers play dice at the festival?" In this variant, there is no mention made of the influence on the dicing scene of Kali or any other outside force.

Finally, both candaini and the pandvāni narrative of $\mathrm{Nal}$ and Damayanti are love stories in which the love is first characterized by the heroine's selfchoice and then her determination to hold onto that choice against overwhelming odds. The heroes of both stories are seemingly less committed to their love when obstacles are placed in their way. Lorik gets cold feet and tries to back out of the elopement several times before he is almost literally dragged by a washerwoman to the tree where he is to meet Candaini; $\mathrm{Nal}$ carries the message of the gods to Damayanti with the suggestion that since they are gods, whose anger can destroy the world, she should really choose one of them as her bridegroom.

The heroines, however, are undeterred in their choice. Damayanti asserts that the choice she has made in her heart, long before the swayamvar, is equivalent to marriage itself: "I've already accepted you as my husband; I'll marry no one else." Furthermore, she orders Nal to take this message back to the gods, with the following instruction about the nature of true "selfchoice" in the swayamvar: "The meaning of a swayamvar is that one chooses according to her heart. In this darbār [court], there is no fear; there is no force. Whomever the girl garlands, that is her husband. Whomever I desire, that is whom I will garland. There's no sin in this, no reproach; it's nothing like that. Go and tell them this!"

Kali, the god who is angered over having missed the first swayamvar and instigates Nal's downfall in the dicing match of the Sanskrit variant of the narrative, in the Chhattisgarhi version later criticizes the heroine for this very independence, which she had declared to be above reproach at a swayamvar: "This ordinary [sādhāran] girl is too proud [ghamand; thinking she can choose a human over the gods]. I'm going to tear apart this union," which he succeeds in doing only temporarily.

The traditions of candain $\bar{\imath}$ and $\mathrm{Nal}$ and Damayanti characterize an ideal love as one of not only erotic passion but also companionship. The forest scenes give literal space for this companionship to be externalized. Candaini and Lorik face obstacle after obstacle together, alone against the world they encounter in foreign countries and the jungle. They cook together, make rafts together, plot against and trick enemies together. Of course, the story of $\mathrm{Nal}$ and Damayanti dwells on the betrayal of just such companionship. 
In summarizing the story for me outside of performance, one singer started with the frame story of the Mahabharata hero Yudhishthira:

The story begins here: there was Arjun; Arjun leaves them all, the four [other Pandava] brothers and Draupadi; . . and over here, there's Bhim; Bhim also goes by himself to wander; Dharm Raj is left all by himself, Yudhishthira. ...

[A rssi finds the weeping king, who complains,] "What's the use of having so many brothers and such a big family? There's no one in the world with greater grief than I have. ... Having left behind such a large kingdom, leaving the entire family, I have come into the jungle . . . but . . . now there's no one here to give me companionship."

The rssi, standing in front of him, says, "Son, do you think that you're disconsolate? You're most fortunate; you won't find anyone so fortunate, even if you look. . . . I know everything: that your kingdom has been lost, your brothers defeated. You came to do tapasya [austerities] in the jungle, and now in the jungle, you have no company. ... Son, if you think you're disconsolate, you haven't even seen sorrow. What you think of as sorrow is actually your flower. What is sorrow like? Let me tell you about Raja Nal."

[The singer continues,] Whoever tells the story in our caste [Sahu] has to start the story with this question, "What is sorrow; what is happiness?"

Yudhishthira's sad state is attributed by the rși as one resulting from lack of companionship; by so framing the story that follows, he characterizes the sorrowful separation of the lovers $\mathrm{Nal}$ and Damayanti as the loss of companionship. Yet the tale of sorrow that follows is actually more that of Damayanti's sorrow than Nal's.

Another singer elaborates on what true companionship means in the uniquely Chhattisgarhi terms of ritual friendship (ritually solemnized friendships between same-sex, cross-caste friends). This test of true friendship/ companionship, rather than that of erotic love alone, is the test that the hero $\mathrm{Nal}$ fails. In this performance, Damayanti responds to $\mathrm{Nal}$ when he tries to persuade her to leave him in the forest and return to her mother's place:

[She first calls on shastric authority and then switches to "Chhattisgarhi" authority when she recalls the mode of ritual friendship (mahāprasād).]

The śástra say, "Whatever patience, whatever stamina a man has, it will be tested [parikśa]. Whatever dharma he follows, the test of that dharma is the test of friendship: that is, [the test of] mahāprasād, phülphülvāni [names of specific kinds Chhattisgarhi ritual friendships]-these are tested.

One could say a woman's test is calamity. Yes, it's good to have a mahäprasād friend and for this friendship to survive calamity. Whoever stays with another 
in sorrow and happiness, that is the friendship of mahāprasād. . . You're experiencing such suffering, such trouble; I won't leave you, my master.

The king then understood that she was no ordinary woman who would leave him.

\section{A Performative Crossroads of Two Poetics}

In contrast to the candaini tradition, pandvān $\bar{\imath}$ has been picked up by many "shastric," Ramayana performance troupes. The consecutive, year-long television serializations of the Ramayana and Mahabharata that riveted India in the late I980s have placed these two traditions in a performative/generic relationship with each other that did not traditionally exist in Chhattisgarh; the Ramayana tradition is dharmic/shastric, whereas pandvān $\bar{\imath}$ is regional, local, not normative in the sense that the shastric devotional text of the Hindi Rāmcaritmānas is. It is difficult to say whether the television phenomenon "permitted" Ramayana performance troupes to add pandvāni to their repertoire by legitimizing the Mahabharata in some way, or if this innovation has been in response to the increasing popularity of pandvāni in Chhattisgarh itself.

Let's look more closely now at a performance by such a troupe, whose repertoire includes rāmsaptah, pand $\bar{d} \bar{a} \bar{n} \bar{i}$, and periodically even candain $\bar{\imath}$ (although Ramayana performances are most common). As its lead singer says, "Whatever people call us for, that's what we'll sing." The newly emerging performance configuration between pandvānī and Ramayana has influenced the pandvān $\bar{i}$ performance style of this troupe dramatically. In the performance under consideration, the performer negotiated between a regional poetics and a more shastric and devotional poetics, a Ramayana-like performance style, incorporating elements of each. This particular audience, however, still understood pandvāni to be firmly situated within the regional repertoire. This variance in the intertextual context the audience and singer brought to the performance resulted in audience-performer negotiations at some point and, finally, for the audience, a disappointing ending.

In my search for Damayanti in the Chhattisgarhi countryside, I had initiated this performance, although it played itself out before a "traditional" audience in a Gond neighborhood on the outskirts of the town of Dhamtari. I had learned of the lead singer, Manmohan Sinha, from a man who periodically had performed with his troupe and who was a neighbor of the Gond friends I was visiting. The performance took place in the front courtyard of their house, next to the major thoroughfare of the villagelike neighborhood.

Manmohan is a forty-five-year-old high school graduate who makes his 


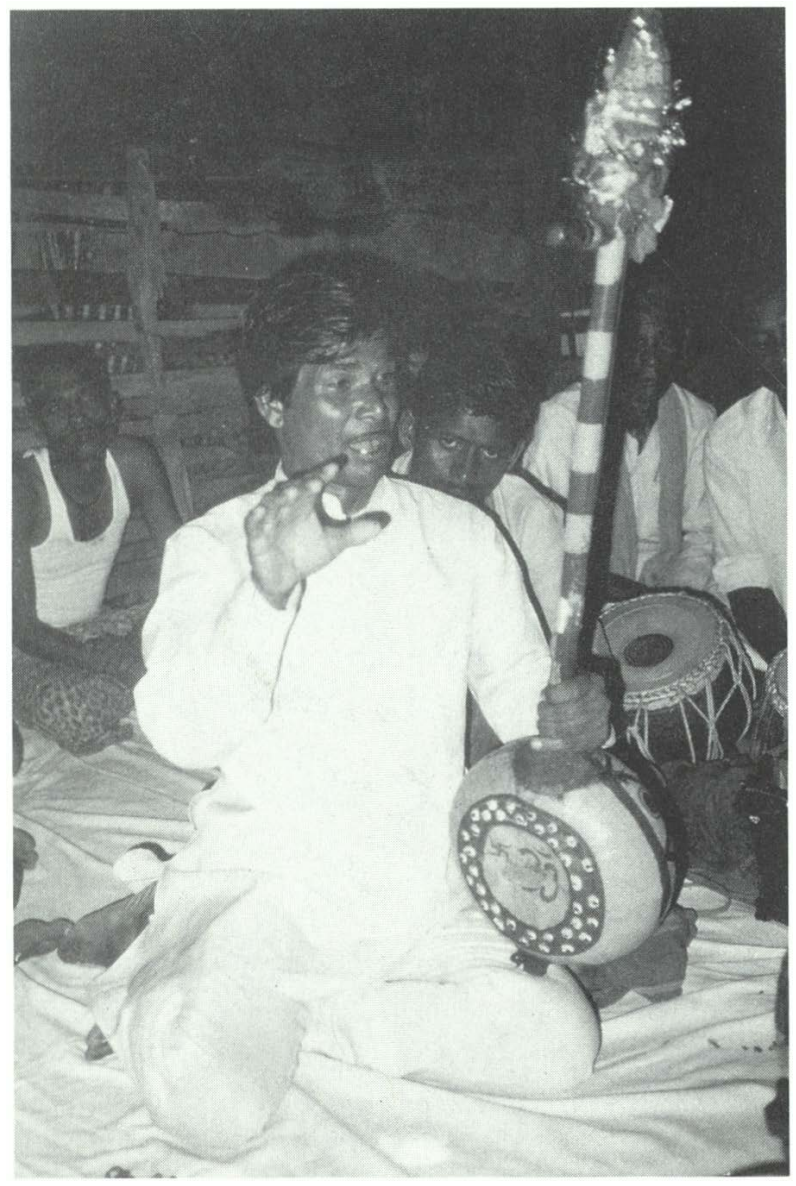

Pandvānī singer Manmohan Sinha, holding the characteristic tambūrā, Dhamtari, Raipur plains.

living as a day laborer (and was, at the time of this performance, hired as a construction worker). He said his grandfather had also been a professional performer; and it was from him that he had learned "whatever it is that I know." After what I, as a nontraditional pandvāni patron, felt to be some rather awkward negotiations of an appropriate performance fee, Manmohan agreed to come the next night to perform for three hours. He contemplated whether he would be able to sing the entire $\mathrm{Nal}$ and Damayanti kath $\bar{a}$ in that time but concluded it would, with some effort, be possible. He was rather emphatic that, after working all day in I I s-degree heat, he would not be able to perform longer than this. The initially scheduled performance was can- 
celed because of an unexpected, dramatic hot-season downpour. My Gond hosts assured me, however, that the troupe would show up the next night, since I had given Manmohan a "good faith" down payment; and they did.

Arriving at 9:30 from a village five to seven kilometers away, the performers were served tea and bị̂ $i$ before Manmohan carefully unwrapped his brightly painted and decorated tambūrā, creating a key performance frame for pandvāni as a Chhattisgarhi, rather than "Hindi," performance. He set up a large lithograph of the divine baby Krishna on a folding chair at one end of the courtyard, performed $\bar{a} r t \bar{\imath}$ (lamp offering to the deity), and lit incense. By this time, word of the troupe's arrival had spread through the neighborhood, and an audience of approximately fifty had gathered, two-thirds of whose members were middle-aged or older women. As Manmohan was setting up, I asked several of the women whether they knew this kath $\bar{a}$ of $\mathrm{Nal}$ and Damayanti that was about to be sung. They assured me that it was common knowledge, but one woman said she (and probably most of the others) had not heard it performed for ten or fifteen years. "Still," she said, "we should know it, shouldn't we?"15

Manmohan's opening scene is that of the geese (haris) who, through their descriptions of the beauty of our hero and heroine, "awakened the bhāv (emotion) of love in the hearts of Nal and Damayanti. ${ }^{16}$ Love was born on both sides." The katha is set up, then, as a love story, one whose full ripening is assured when the performer then calls upon the authority of Swami Tulsidas, author of the authoritative Rämcaritmānas (which came as a complete surprise to me, based on my experience of more traditional pandvāni performances), whom he quotes as having said:

If love remains true,

If love one for another remains steadfast,

Then the two will surely meet each other.

One will receive the other.

In this variant, the gods come to Damayanti's swayamvar not as serious contestants but to test the unusual love about which they have heard. The gods say, "We'll go to the swayamvar. If their love is that great, we'll go to test it. If

${ }^{15} \mathrm{Nal}$ and Damayanti is not part of the recorded repertoire on radio or television of either Ritu Varma or Tijan Bai (as of summer I 993). In the cassette tape stores of Raipur's bazaars, I was able to locate two cassette tape recordings of Tijan Bai and one of Ritu Varma, titled, respectively, subhadrā haran (The Seizure of Subhadra), abhimanyu vadh (The Slaying of Abhimanyu), and kuntī aur gandhārī dvārā śiv pūjā (Kunti's and Gandhari’s Worship of Shiva).

${ }^{16} \mathrm{He}$ did not provide the Yudhishthira frame story, which the singer mentioned earlier had told me was crucial to its performance. 
the love is true, from the heart, then, we'll have to find out about it; we'll have to test it."

When the four gods come to the ceremony, all in the guise of $\mathrm{Nal}$, Damayanti calls on the goddesses Sharada Mai and Sarasvati Dai; but then "an idea comes to her" to appeal to the gods as a daughter (the same strategy used with the hunter in the jungle):

Prostrating at their feet, joining her hands, Damayanti said, "You're the father; I'm your off spring, like a daughter. With my heart, words, acts, and soul, I've [already] accepted Raja $\mathrm{Nal}$ as my husband. Protect me, help me, so that I can identify $\mathrm{Nal}$, so that I can garland Nal.

I'm like your daughter; I'm dependent on you. ... And if you test me in this, if you challenge me, and I can't identify Nal, I'll commit 'suicide'! All my faults and sins will be on your heads."

[Rāgi responds,] 'Murder' will be committed.

"All my faults and sins will be on your heads." In this way, Damayanti spoke to the gods; and the gods understood that her love was genuine. "Her love is absolutely true; it's a love from the heart. She has 'passed' the test of love. She's succeeded. We'll give her our true darśan." And the four gods took their true forms and went away.

Of course, the rest of the narrative continues to test that love; it is guaranteed fruition not only because of Tulsidas's reassurance that true love is rewarded (particularly in the context of devotional texts) but also because of the intertextuality with genres such as candain $\bar{i}$, in which the heroine is resourceful and clever and finally succeeds in achieving her goals.

But now, to return to Tulsidas's voice of authority-it suggests a shastric performance frame for the Ramayanization, if you will, of pandvāni . We will see that this process is not complete, however, and finally causes the audience some consternation. The narrative recitation of the lead singer is interspersed with sung portions by the mandali (performance troupe) of men accompanying him. Some of these songs simply repeat or elaborate what the lead singer has sung; but many others end with lines that approximate those of Ram bhajan (devotional hymns), unrelated to the narrative story line. For example, Manmohan sings of the gods' meeting with $\mathrm{Nal}$ on his way to the swayamvar:

[Spoken] The gods arrived in front of Raja Nal and said:

[Sung, with accompanying musicians joining in]

Oh Siya Ram, Lakhan, Siya, Ram; oh Ram, oh Siya Ram. 
The gods spoke, oh Ram, Siya Ram; they joined their hands and spoke, oh Ram, Siya Ram. ${ }^{17}$

These bhajan-styled songs, usually ending with the line, "Bolo brndàvan bihāri läl ki jai" ("Recite/speak the praises of Brindavan's Biharilal [the god Krishna]"), are the most obvious indication that the lead singer has situated his pandvān $\bar{i}$ performance in a shastric bhakti (devotional) repertoire and intertextual sphere. He also uses periodic bhakti idioms in the narrative line itself, such as that voiced by Damayanti when she expresses her commitment to Nal as her husband when he brings the message from the gods that they will be coming to her swayamvar: "Ever since I heard your praises from the geese, I've worshiped [ $p \bar{u} j \bar{a}$ ] you like a god. If I marry anyone, it will be you. Maharaj, whatever happens, I don't want the happiness of heaven. I want only the happiness of your feet [caran]. I'll be content only in your service [sevā]. I won't marry anyone else." The word used for worship ( $p \bar{u} j \bar{a})$ carries specific connotations of worshiping a deity, as does the word seva when associated with $p \bar{u} j \bar{j}$. So, too, the word caran is used in devotional contexts, rather than the more colloquial Chhattisgarhi word for feet, pair.

Echoes of the shastric and Chhattisgarhi repertoires with which Manmohan's performance of $\mathrm{Nal}$ and Damayanti is in dialogue continue to play off of each other throughout his performance. Even as he is citing Tulsidas or singing Ram-type bhajan, a consistent relationship with the Chhattisgarhi performance repertoire is maintained through the instrumentation and especially through the active dialogue with the ragg $\bar{l}$ (companion), whose hă, ho, or humorous one-line responses (often misinterpretations of particular words used by the lead singer) literally punctuate the performance, line by line, even phrase by phrase.

Two and a half hours into the three-hour performance, Manmohan had carried the narrative only as far as the swayamvar. He told his audience, "Time is precious; I'm going to have to shorten this a bit," to which the rāg $\bar{\imath}$ responded, "Yes, hurry it up!" This created a dramatic break in the performance rhythm. The singer intended to skip over the wedding with the cryptic line, "And so, according to our Hindu 'customs,' the wedding was fulfilled and wedding songs were sung." But the women of the audience insisted on more - that the Chhattisgarhi bride Damayanti be sent off to her sasural (in-laws' place) with the appropriate wedding songs, Chhattisgarhi viha git (one of the genres regularly mentioned as part of the Chhattisgarhi performance repertoire). Manmohan resisted their pleas and tried to con-

17 "Siya Ram, Lakhan" is a variant of "Sita Ram, Lakshman," which are the names of the hero, the heroine, and Ram's brother, of the Ramayana. 
tinue; after all, vih $\bar{a}$ git are an exclusively female genre. But, the women prevailed, and reluctantly, the entire mandali launched into the wedding songs in a dehāti (village) Chhattisgarhi. The initial song brought on a much longer description of the wedding itself, followed by more $v i h \bar{a} g \bar{i} t$, this time sung with full enthusiasm. (The traditional pandvān style of "former days" with its short sung lines would not have allowed for this kind of innovative localization and response to the audience.) These songs, then, firmly established Damayanti as a Chhattisgarhi bride and the women of the audience as key participants in the shaping of the performance, women who became noticeably more verbal and interactive after this incident. ${ }^{18}$

The expectations of the shastric/bhakti performance style and that of Chhattisgarhi pandvāni came into direct conflict only at the very end of the performance. By I:30 in the morning, Nal and Damayanti had only reached the crossroads in the jungle, where, exhausted, Damayanti fell asleep. Like the Sanskrit hero, Nal experiences great inner conflict about whether to leave Damayanti; but he finally turns from her:

He was of two minds, arguing back and forth.

Half said, "Yes, yes"; but he came back.

He saw in front of him the body of Damayanti.

He cried ... tears filled his eyes.

There, a king's daughter, sleeping without being bid farewell.

He went and came several times; but Raja Nal finally left Damayanti.

[Song]: My queen was left all alone, bhā̄ya mor [the panduānī performative end phrase].

He left her all alone in the jungle.

The singer then describes the nature of the "vehicle" of a household, one needing both man and woman, that has now been broken: Nal leaves the union, alone; Damayanti awakens and calls out for her partner but realizes she has been left, alone. Manmohan ends the narrative performance with the line: "The woman was left alone in the jungle"-Damayanti abandoned at the crossroads. And the audience is left with the closing frame: "Bolo brundàvan bihāri läl kì jal." Turning to me, Manmohan asked that I turn off the tape recorder, then said, "It's late. I'm finished."

${ }^{18}$ In Chhattisgarhi women's Ramayana mandali performances of the episode of Sita's wedding, the narrative is feminized by the elaboration of the wedding scene, the bride taking leave of her maternal home, and the singing of wedding songs; but the songs are not drawn from the Chhattisgarhi repertoire, for Sita is not a Chhattisgarhi bride, not "one of us." 
The women in the audience were aghast, "But you can't leave our daughter in the middle of the jungle!" Manmohan answered simply, "Well, you know the story." Perhaps the performer was capable of suspending the performance in the middle of an episode because of the influence of the traditional shastric style of the Ramcaritmannas performance, where the goal is to create and elaborate the various bhāv of bhakti rather than to sustain a narrative. V. Narayana Rao has articulated this difference as one between performances whose purpose is "communion" and those whose purpose is "communication" (oral communication, May 1992). In the recitation of a devotional text, an episode or scene may be suspended midway, to be picked up again the next day or the next week. But this is a bhakti aesthetics. Here, in a Chhattisgarhi performance, for an audience of Chhattisgarhi daughters, it was not acceptable to leave Damayanti at the crossroads over night, and the women were still complaining at the community tap (nal) the next morning as they filled their water vessels. Perhaps this image, more than any other, articulates what it means for the Chhattisgarhi pandvāni to be sung "according to our hearts." 